Makale Geliş | Received: 29.08.2018

Mavi Atlas, 6(2)/2018: 282-303.

Makale Kabul | Accepted: 10.09.2018

DOI: 10.18795/gumusmaviatlas.455765

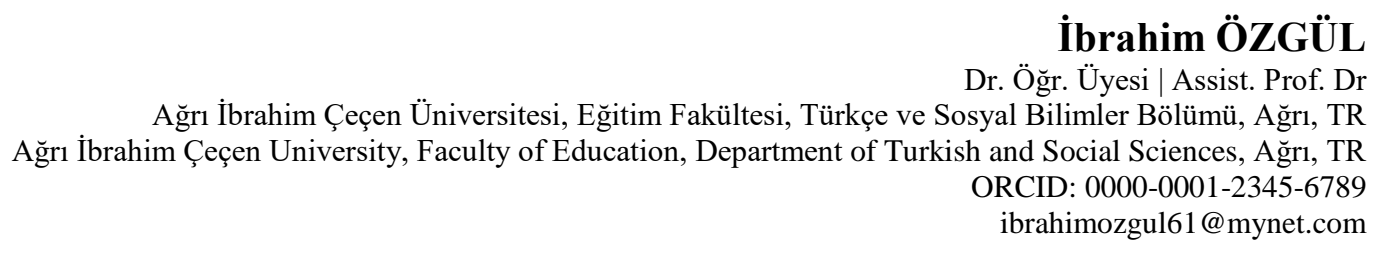

\title{
Sultan II. Mustafa Döneminde Osmanlı’daki Eşkiyalık Faaliyetleri
}

Öz

Eşkiyalık, silahla veya çeşitli yöntemlerle zor kullanarak halkın can ve mal güvenliğini tehdit eden, kamu düzenini bozan bazı şahıs ve grupların organize olmaları sonucu asayişi ihlal faaliyetler olarak ortaya çıkmaktadır. Bu tür faaliyetler bazen zaman ve mekan bakımından geniş döneme yayılmış ve devleti uğraştıran olaylar şeklinde cereyan etmiştir. Bu çalışmada döneme ait bilgiler belgeleriyle ortaya konulmuştur. Bu faaliyetlere zaman zaman taşradaki devlet görevlilerinin de eşkıya grupları oluşturarak veya onlarla birleşerek teşebbüs ettikleri de olmuştur. Bu tür faaliyetler daha çok sarp geçitlerin

bulunduğu, güvenlik zafiyetinin olduğu 1ssız yerlerde meydana geldiğinden devlet devamlı tedbirler almaya çalışmıştır. Devlet bu tür olayları önlemek için çeşitli tedbirler alırken suçun isbatı ve yargılama usullerini hukuk kuralları doğrultusunda kesin, açık ve objektif delillerin kullanılmasına dikkat ederek araştırma sonucunda cezalandırma yoluna gittiği kullanılan arşiv belgelerinde açıkça görülmektedir.

Anahtar Kelimeler: Hüküm, Kadı, Eşkıya, Şikayet, Soygun,

\section{Banditry Incidents in II. Mustafa Period in Ottoman State}

\begin{abstract}
Banditry is an illegal activity caused by some organized people and groups who threaten the security of life and property of other people by using force with arms or various methods that disrupt public order. Such activities which caused long-termed and extensive struggles for state have been revealed with documents in this study. This kind of activities were occasionally attempted by the state officials in rural areas either by forming bandit groups or by unifying them. The state tried to take various and perpetual measures because such activities have become more frequent in steep passages, desolate places and insecure areas. While the state took various measures to prevent such incidents, it is evident in the archival documents that trial, judgment and punishment processes were conducted by paying attention to use of definite, clear and objective evidences in accordance with the rules of the law.
\end{abstract}

Keywords: Judgment, Kad1, Bandit, Complaint, Robbery, 


\section{Giriş}

II. Mustafa, amcası II. Ahmet'in 7 Şubat 1695 tarihinde vefatı üzerine ve ailenin en büyüğü olması nedeniyle hiçbir zorlukla karşılaşmadan otuz iki yaşında Osmanlı tahtına oturmuştur (Uzunçarşı11, 1973: 558). Hem babası IV. Mehmet’ten hem de iki amcasından daha iyi tahsil görmüş, eski padişahlar gibi dönemin iyi hocalarının elinden ders almış, kabiliyetli, şair, musikişinas ve hattattı (Öztuna, 1983: 75). II. Mustafa tahta çıktığı yıllarda II. Viyana kuşatmasıyla başlayan çok uluslu savaşlar çeşitli cephelerde bütün hızıyla devam etmekteydi. Tahta geçer geçmez devletin kontrolünü sağladıktan sonra ordunun başında sefere çıkma isteğini bildirdi. Sakız Adası'nın Venedikliler'den alınması Osmanlı toplumunda büyük memnuniyetle karşılandı. Birçok cephede birden savaşan Osmanlı Devleti, vergilerin artırılması, kapıkulu ve tımarlı sipahilerin yapılarının bozulması nedeniyle halktan asker toplama yoluna gitmiştir. Bunlar savaş sona erince memleketlerine döndüklerinde savaşlar nedeniyle görev mahallinde bulunmayan idarecilerin yokluğundan da istifade ederek eşkıyalık hareketlerinde bulunup, sosyal ve ekonomik yapının sarsılmasına yol açmışlardır (Özcan, 2006: 275-280).

II. Viyana kuşatması sonrasında 16 yıl süren savaş dönemi, Osmanlı Devleti’ni mali ve idari açıdan büyük buhranlarla karşı karşıya bırakmıştır. Savaşlar sebebiyle gelir gider dengesi bozulmuş, devletin önemli tarım toprakları, maden vs. türü işletmelerinin harp alanları içerisinde kalmasından dolayı bu gelirlerden tamamen mahrum kalınmıştır. Devlet, gelirler giderleri karşılamayınca ordunun finansmanı için yeni ve geçici vergiler toplamıştır. Vergilerden muaf olan asker ve ulema da konulan "imdad-1 seferiyye" vergisini vermekle yükümlü kılınmışlardır. Diğer yandan savaş yıllarında asker kadroların şişmesi ve maaş giderlerinin artması ve yöneticilerinin de cephede olmasının doğurduğu idari boşluk ve ekonomik güçlüklerinin de artmasıyla eşkıyalık faaliyetleri yaygınlaşmıştır (Afyoncu, 2006:115-116).

II. Mustafa, Sakız Adası seferinden sonra uzun hazırlıklar yaparak 1695'de Avusturya seferine çıkarak burada da başarılar kazanmıştır. Padişah 1697 yılında Avusturya seferine 100 bin askerle çıkmıştır. Yapılan savaşlar sonucunda yer yer başarılar kazanmışsa da Zenta bozgunuyla komuta kademesinin önemli kısmı ve askerlerinin bir kısmı şehit olmuştur. Zenta Vakası Osmanlı Devleti’nde barış temayülünü artırmıştır. Avusturya'nın da barışa taraftar olması 1699'da yapılacak olan Karlofça barışına giden yolu açmıştır (Orhunlu, 2006: 695-700). Zenta mağlubiyetinin II. Mustafa üzerinde tesiri büyük olmuştur. Padişah savaşı sürdürmek istiyordu. Barışa olan ihtiyacın da farkındaydı. Fakat böyle bir isteğin Osmanlı Devleti’nin itibarını sarsacağını 
ve teklifin kendisinden gelmesinin durumu daha da vahim hale getireceği kanaatindeydi (Osmanlı İmparatorluğunun Yükseliş ve Çöküş tarihi, III. 288, Akt. Özcan, 2006: 275280).

II. Mustafa döneminde zaferler ve bozgunlar yaşanmış, Osmanlı Devleti’ne karşı birleşen Avrupalı güçlerle yapılan Karlofça Antlaşması'yla Osmanlılar ilerleme pozisyonundan savunmaya geçmiş ve toprak kaybetmiştir. Bu gidişatı durdurmak için Avrupa'nın üstünlüğünü sağlayan gelişmeleri takip etme yönünde bir eğilim doğmuş, özellikle ordu düzeni ve silahların yenilenmesi yoluna gidilerek reformlar yapılmıştır. Bunların yeni ve eskinin bir türevi olarak ortaya çıkmaları, daha sonra XIX. Yy’daki yeniliklerin öncüsü olmuşlardır (Shaw, 1994: 304-311).

Karlofça Antlaşması'nın ardından beş yıllık dönemde alınan bu askeri ve mali tedbirler II. Mustafa'ya karşı pek çok kesimin muhalefetine yol açmıştır. Ayrıca Zenta yenilgisinden sonra kendisini babası gibi zevk ve eğlenceye vermesi ve toprak kayıplarının doğurduğu memnuniyetsizlik doğrudan kendisini hedef alarak tarihte Edirne Vakası denilen olayların patlak vermesi sonucu 3 Eylül 1703 tarihinde tahttan indirilerek yerine kardeşi III. Ahmet getirilmiştir (Özcan, 2006: 275-280). II. Mustafa 8 yıl 6 ay 14 günlük saltanatından sonra 29 Aralık 1703 tarihinde ölmüştür (Uzunçarşı11ı, 1973:558).

XVI. yy’ın ortalarından sonra her alanda dayanılması güç bir darlık yaratan ekonomik sarsıntının devlet ve toplum hayatındaki yıkıcı etkileri; devlet düzeninde aksamalar meydana getirirken akçe değerinin düşmesiyle değişmeyen vergi gelirlerinin hazinenin giderlerini karşılamaması nedeniyle daha çok para bulmak zorunda kalan merkezi yönetim, bir yandan vergileri artırırken diğer yandan mukataaları ihale yoluyla iltizama verdiğinden bu tür vergilere tabi olan reaya ezilmeye başlamıştır. Hizmete karşılık tutulan paranın artan ihtiyaçlara yetmemesi nedeniyle ücretleri nakit para ile ödenen veya kendilerine dirlik bağlanan memurlar, geçimlerini sağlamak için yine reayanın çeşitli sınıflarına musallat olmuşlardır. Köylü toplumu gerek devlet çarkının işleyişinden, gerek özel iş alanlarında köylünün omuzlarına yüklenen ekonomik yük zirai hayatı zorlaştırdığından "çift bozanlık" denen ekilip biçilen toprakların terk edilerek şehirlere göç edip tembel bir şekilde üretmeden tüketmeye başlamaları nedeniyle her yönden tehlike yol açıordu (Akdağ, 1995: 93-97).

Çiftbozan kitlelerden oluşan bu leventlerin çıkardıkları kargaşaları düzenli harekete çeviren, sürekli ve sistemli kılan iç olayların başında yöneticilerin kendi iktidar mücadelelerinde bunları kullanmaları olmuştur. Hatta tımarlı sipahiler de zamanla bunları kendi istekleri için kullanmıştır (Akdağ, 2014: 679-688). Taşrada “ehl-i örf” adı verilen 
yöneticiler merkezi otoritenin sarsıldığı dönemlerde görev yaptıkları yerlerde halktan kanunsuz olarak "nalbaha", "selamlık", "pişkeş", "aylık" gibi adlar altında vergiler toplamıştır. Devletin bu yöneticileri idamla tehdit etmesine rağmen bu suiistimallerinin önüne geçilememesi halkın yerinden ve yurdundan ayrılmasına sebep olmuştur (Afyoncu. 2003: 137-145).

Devlet; vergi yolsuzlukları, salgunlar ${ }^{1}$, kadıların yaptıkları suiistimaller, angarya hizmetler, halk ve askeri zümre arasında devamlı çatışma konusu olan, devlet için genel bir huzursuzluğun ötesinde buhranlara sebebiyet veren bu durumların eşkıyalık ve buhranlara dönüşmemesi için gayret göstermiştir (İnalcık, 2012: 181). Bu nedenle devlet halkı korumak, idarecilerin yolsuzluklarını, halka zulmetmelerini ve usulsüz uygulanmalarını önlemek için genel mahiyetteki fermanlar diye adlandırabileceğimiz adaletnameler yayınlayarak önleyici tedbirleri artırıyordu (İnalcık, 1988: 346-347).

Eşkiyalık, içinde birkaç suçu birden barındırabilen karışık bir fiil olduğundan dolayı herhangi birinin gerçeklemesi yeterlidir (Bardakoğlu, 1995: 463-466). Genel olarak soygun yapan, halkın canına ve malına kasteden, etrafı haraca bağlayanlar için İslam tarihinde "yol kesen" anlamına gelen "harrabe” veya "kuttau't-tarik" tabirleri kullanılmıştır. Osmanlılarda ise ikinci tabire rastlanmakla birlikte ayrıca "şaki, eşkıya, eşirra, Celali, harami, haramzade, haydut” gibi tabirler kullanılmıştır. Eşkıyalık Osmanlıların da yer aldığı Akdeniz dünyasında XIV. yy’da tırmanma eğilimi göstermiş ve XVII. yy'da ise büyük bir problem haline gelmiştir. Bu durumun başlica sebepleri; farklı cephelerdeki savaşların ağır masraflarının halka yansıması, Anadolu'da artan nüfus ve bu nüfusun işsiz kalmasıyla eşkıya topluluklarının insan kaynağını oluşturmasıdır. Osmanlı kırsal hayatını organize eden tımar düzenin bozulması idari, mali ve sosyal düzende büyük tahribat yapmasıyla üretici sınıfın fakirleşmiş olmaları, devlet otoritesinin zayıflamasıyla sefere gitmemek veya seferden firar etmenin yaygın bir hal almas1, vergilerini ödemeyen bir kısım aşiretlerin bulunması eşkıya gruplarının oluşmasını sağlamıştır (İlgürel, 1995: 466-469).

$\mathrm{Bu}$ faaliyetler devletin işleyiş̧ini sekteye uğrattığı gibi vergi toplanmasında pek çok zorlukların da yaşanmasına sebep olmuştur. Yerlerini ve yurtlarını terk eden köylüler devlete birçok problemin kaynağı olmuştur. Bunun yanı sıra vergileri topladığı halde toplayamadığını beyan ederek iki mislini halktan toplayan görevlilerin baskıları sonucu ahali meskun olduğu mahalleri terk etmeye yönelmiştir. Köylüler yetkili mercilere

\footnotetext{
${ }^{1}$ Salgun veya salma: reayadan istenen olağanüstü nakdi vaya ayni vergilerdir Umumiyetle hane başına belli miktarda arpa, buğdaya ve başka yiyecek şeyler toplanmaktan ibarettir.
} 
yaptıkları şikâyetlerde kendilerine uygulanan "eşkıyanın salgun salma, haksız yere tekâlifte bulunma, devir bahanesiyle yaptıkları zulümleri ve baskılarını sıraladıktan sonra; artık bunlara dayanamayacak duruma geldiklerini, eğer bunlara son verilmezse bulundukları diyarları terk edecekleri şeklinde hükümeti tehdit ediyorlardı". Nitekim bu talepler karşılık bulmadıkları yerlerde halkın orayı terk etmesi sonucu birçok sosyal ve ekonomik problemlerin ortaya çıkmasına neden olmuştur (Demirci, 2012: 47-76).

Anadolu’da görülen bu göçler önemli miktarlara ulaşmıştır. Hatta ahalinin bir kısmı Gürcistan’a kadar gitmeyi bile göze almıştı. Köylerini boşaltan halkın önemli bir kısmının erkekleri levent olmuştur. Diğer bir kısmı şehirlere ve kalelere göç ederken sancak değiştirenler de olmuştur. Bunların nerelere gittiklerini tespit etmek için zamanla mukataaları, hasları, vakıfları ve dirlikleri yeniden tanzim etmek yoluna da gidilmiştir (Akdağ, 2014:679-688). Anadolu'da bu grupların çoğalması gibi, Balkanlarda da "hayduk" adı altında toplanan bir takım zümreler oluşturmuşlardı. II. Mustafa bu kabil hareketleri önlemek için, teftişçi ismi ile valiler tayin ettiği gibi, 1696' da “saruca” ve "sekban" kaldırıldığını ilan ederek vali ve diğer idarecilerin bundan sonra mezkur unsurları kapılarında bulundurmamaları tembih etmiştir (Orhunlu, 2001: 695-670).

Eşkıyalığın en büyük organize hali olan Celali isyanları yukarıda zikredilen sebeplerin yanı sıra devlet görevlilerinin baskıları ve taşradaki idarecilerin görevlerini ifa ederken haksız “salgun”lar salarak fazla mal ve vergi toplamaları, halkın devlet merkezine haklı şikâyetlerine yol açmıştır. Halk bir yandan idarecilerin bu haksız tutumlarına bir yandan da eşkıya gruplarının saldırıları arasında kaldıklarında ya daha güvenli bir yere göç ediyor ya da eşkıya (Celali) gruplarına katılıyordu. XVII. yy’ın sonlarından itibaren Osmanlı-İran ve Osmanl1-Avusturya savaşlarından firar eden sipahilerin ayaklanmaları Celâlilik hareketine dönüşmüştür. Bundan sonra Celaliler daha güçlü reisler etrafında teşkilatlı bir şekilde toplanmaya başlamışlardır. Liderleri, genellikle azledilmiş veya haksızlığa uğramış hükümet mensupları ile reaya arasında itibarlı şahıslardan oluşuyordu (İlgürel, 1993:252-257). Celali isyanlarına adı verilen Bozoklu (Yozgatlı) Celal adlı bir tımarlı sipahi Yavuz Sultan Selim zamanında şeyhliğini ilan edip, etrafına 20 bin insan toplayarak mehdiliğini ilan etmiştir. Bu şahıs Tokat-Sivas havalisinde hakimiyet kurunca Osmanlı devleti 1519 yılında yapılan savaşta asileri mağlup edilmiş, reisleri olan Celal de öldürülmüsstür. Bozoklu Celalın isyanı Osmanlı literatürüne yeni bir isim katmıştır. Bu tarihten sonra Anadolu’da isyan edenlere Celale nispetle "Celali” denilmiştir. Celaliler için, ayrıca "eşkıya", "türedi eşkıyası" adları da kullanılmıştır (Afyoncu, 2003: 137-145). 
$\mathrm{Bu}$ şahısların en büyüğünden en küçüğüne kadar bütün Celali şefleri resmen padişahın kendilerine verdiği sıfatları taşıyorlardı. İçlerinde ümera sınıfına mensup olanlar bulunmakla beraber sipahi oğlanları, zaimler ve devriye bölükleri birlikte isyan ettiklerinde bunların fiili görevleri maiyet memurluğu idi (Akdağ, 2014: 679-688). Bunlardan görevden azledilen devlet görevlileri haksızlığa uğradıklarını ileri sürerek isyana kalkıştıklarında ehli örf oldukları için halk bunlara kolaylıkla itibar etmekteydi. Eşkıyalığın belli bir ideolojisinin olmadığı bilinmektedir. Aslında Celali isyanlarının amacı devleti yıkmak veya ele geçirmek değildir. Mücadelede kanun dışına çıkmamış yöneticilerle kanun dışına çıkmış yöneticilerin birbirleriyle olan çatışmasında halkın her iki tarafta da yer aldığı olmuştur (Ünal, 2017: 3-10).

Devlet eşkıyalığı bastırmak için son derece faydacı davranarak önce mahalli güçlerce isyanı bastırmakta; o da olmazsa merkezden vezir, serdar tayin edilerek halletmek yoluna giderdi. O da yetersiz kalınca pazarlık sonucu çeşitli mansıplar verip devlete bağlı duruma getiriyordu (Ünal, 2017: 3-10). Bütün bu tedbirlere rağmen Celali isyanlarının kesif bir hal alıp Anadolu'yu adeta bir savaş alanına dönüştürünce ve devlet bütün tedbirlere rağmen isyanı bastırmakta çaresiz kaldığında liderleri affetmek ve bunları genellikle Rumeli'de serhat bölgelerindeki görevlere getiriyordu. Halktan da yerini yurdunu terk edenlere geri dönmelerini teşvik amacıyla birkaç yıl vergi muafiyeti getirmek bulundukları yerleri şenlendirmek gibi cazip hale getirerek dönüşlerini teşvik ediyordu (Ünal, 2017: 3-10).

Osmanlı Devleti bu yola baş vurmakla; devletin gücü, toplumsal grupların feda edilmesiyle değil, devletin bu grupları kendisiyle bütünleştirmesi ya da meşrulaştırması ve kendine bağlamasıyla artmıştır. Avrupalı muhalifler bertaraf edildi, Osmanlı muhalifleri ise evcilleştirildiler (Karen, 2016: 1-2).

Bunun en önemli örneklerinden biri de, "1606 Mayıs'ında, Celali lideri Canboladoğlu, I. Ahmed'e mektup yazarak, padişahın kendisini Halep valisi yapması, yardımcılarına da başka mevkiler vermesi karşılığında, emrindeki eşkıya ordularını paralı asker olarak savaşa yollayabileceği önerisinde bulundu. Mektubun kenarında, padişahın kendisinin düştüğü çok çarpıcı bir derkenar bulunmaktadır. I. Ahmed, "Bu kadarı da fazla. Bu kadar çok şey nasıl verilir?" diye yazmıştır... devletin bu eşkıyaları, böyle anlaşmalar, pazarlıklar ve himaye ilişkileri aracılığıyla denetim altına almayı, manipüle etmeyi istemesi ve becerebilmesi başa çıkması, zayıflığının değil gücünün kanıtıdır." (Ünal, 2017: 3-10). 


\section{Mustafa döneminde meydana gelen ve asayişi bozan hadiseler:}

\section{Anadolu’daki Olaylar:}

Ferdi bir soygun sonucu Valide Sultanın Kethudalığını yapan Hacı Mehmedin mallarına el koyan şahsın yakalandığı ve bu şahsın zapt ettiği para, altın ve diğer malların mübaşir marifetiyle tespiti yapılarak gönderilmesine dair emirde: Vâlide Sultân kethüdâlığı hizmetinde olan El-Hâc Mehmed Ordu-yı Humâyunum'a arzda bulunarak bundan önce bin yüz yedi senesinde Tekirdağ civarındaki yolda arabaları İvaz adındaki kişi tarafindan soyulmuştur. Bu kişinin yanında tuttuğu ve adı zikredilen şahsın malından yüz yirmi kuruş, bir beygir ve sair eşyayı zapt ettiğini ve bu şahsın Çorlu'da yakalanmış olup beraberinde ele geçirilen para ve altının tayin olunan mübaşir marifetiyle gönderilmesi hususunda emir yazılmıştır. Fî Evâil-i Zâ Sene 1107 / 7 Haziran 1696 (BOA.MD 108-1107).

Konya ve Ilgın tarafında peyda olan ve büyük gruplar şeklinde yörede halkın can ve mal güvenliğini sarsan, bölgenin asayişini bozarak günlük hayatı çekilmez hale getiren hareket halindeki eşkıya gruplarının ortadan kaldırıması için Anadolu valisi vezir Mustafa Paşa'nın emrinde bölgede bulunan üst düzey yöneticilerle birlikte kanun üzere işlem yapılarak bunların ortadan kaldılması ve yine o bölgede geçmekte olan Kıbrıs hazinesi ve vefat eden Rakka valisinin servetinin emniyet içinde Ordu-yı Hümayuna ulaştırılmasında bir ihmalin olmamasına çalışılarak koordineli bir şekilde eşkiyanın takibi ve ortadan kaldırılması için hukuk dahilinde mücadele edilmesiyle ilgili hükümde: Konya ve Ilgın taraflarında bulunan köy ve kasabalarda olan kurada ikişer ve üçer yüz parçalar halinde gezen yol kesen eşkıyası halkın canına ve malına kasteden, vilayet sakinlerinin ihtiyacını gideren sebil malları ve değirmenlerini tahrip ettikleri, halka çirkin davrandıklarından dolayı bu eşkıyanın ortadan kaldırılması için gerekli tedbirlerin alınması hususunda; acil lazım olan mühimmattın temininde, Anadolu valisi vezir Mustafa Paşa, Karahisar-1 Sahib Sancağı'na mutasarrıf Mevlüd Mehmed, Sultan Öyüğü ve Akşehir sancakları Begi Şatır Mehmed ve askerlerinin adı geçen vezirin emrinde görevlendirilerek eşkıyanın bulundukları mahallerde ve etkin oldukları mahallarde ortadan kaldırılması emri verilmiştir. Verilen mücadele halka eziyet edilmeden kanun üzere yapılan iş ve işlemler sonucu şakilerlerin cezalandırılmalarının sağlanmasına önemle vurgu yapılmıştır. Yine o güzergahtan gelmek üzere olan Kıbrıs hazinesi ve Rakka valisi müteveffa Hüseyin Paşa'nın mal ve eşyasını mübaşirleriyle birlikte emin ve salim şekilde Ordu-yı Hümayuna ulaştırılmasını, yol üzerinde bulunan halka her hangi bir angarya yüklenmesinden sakınılması buyrulmuştur. Evâil-i 1107 / Temmuz 1695 (BOA.MD 108-829). 
Ordunun sefer hazırlıklarını yaparken sefere çıkmadan önce eşkıyanın olabileceği güzergahların güvenli hale gelmesi için yardımcı kuvvetlerin dahil olmadan önce görevlendirildiklerine dair belgede geçen: Anadolu Beylerbeyi Seyyid Ahmed'in Aydın, Saruhan, Menteşe bölgesindeki piyade ve süvarinin zaman kaybettirilmeden Edirne sahrasına ulaştırılırken gerek bölge de gerekse askerin içinde eşkıyanın barındırılmaması, bir isyana mahal vermeden bunların titizlikle temizlenmesi için görevlendirilmiştir. $\mathrm{Bu}$ görevi ifa ederken halka zarar vermeden yürütülmesi için de üç bin kuruş ödeneğin tahsis edildiği ve bunun geciktirilmeden yerinde kullanması, kuvvetlerin zamanında Edirne sahrasında bulundurması ile ilgili emir gösteriyor ki ordunun içinde de art niyetli kişiler bulunmuştur Evâil-i Za. Sene 108 / 26 Mayıs 1697 (BOA.MD 110-28).

Anadoluda bulunana eşkıyanın üç koldan temizlenmesi için Sarayönü sancak beyi Ömer Bey sol koldan, malatya sancak Beyi rişvanoğlu Halil Bey sağ koldan, Anadolu Beylerbeyi Seyyid Ahmet Bey de orta kolda görevlendirilmiştir. Anadolu'nun eşkıyadan temizlenmesi için koordineyi aksatmadan ve halka zarar vermeden eşkıyadan eser kalmayıncaya kadar faillerin cezalandırılarak asayişin sağlanması hususunda verilen emirde bu dönemde yine eşkıyalık faaliyetlerinin vardığı noktayı ortaya koymaktadır. Evahir Z sene 1108 / 17 Temmuz 1697 (BOA.MD 110-345).

Eşkıyanın sadece yol kesme soygun, cinayet işlemedikleri zamanla da bir bölgede alınması gereken vergilerin toplanması esnasında engel oluşturmak için bazı insanları kullanarak tahsilatı engelledikleri, görevlileri darp ettikleri tespit edilen altı eşkıyanın yakalanarak Amasya kalesine haps edilmeleri istenen hükümde: Sultân dâmet ismetuhânın kethüdâsı Hacı Mehmed arz-1 hâl idüp Valide Sultan Hassı topraklarından Ortapare Hassı malından Çongarlu Cemaati'nin ödemeleri gerekli olan vergilerin tahsili için Voyvoda Seyyid Halil tarafından adam gönderildi. Adı geçen cemaatten Demirci İlyas, Musa Kethüda, Halil Kethüda, Köle Ebubekir ve Minnet Bölükbaşı oğlu Hasan adındaki eşkıyalar kendilerine tâbi' bazı kötü insanları toplayarak vergilerin toplanmasına mâni olmuşlardır. Ayrıca adı geçen voyvodayı darp ettikleri, bu şahısların devamlı bu tür faaliyetlerde bulunduklarından, acilen bunların durumlarının araştırılarak fesâd u şekāvet üzere olanları Amasya kalesine hapsedilmeleri hususunda hüküm istenmiştir. Gelen cevapta; mahallinde kötü halleri tespit edilen altı eşkıyanın Amasya kalesinde hapis olunması yazılmıştır. Fî Evâsıt-ı Z Sene [1]108 / Temmuz 1697 (BOA.MD 109-13).

Bâzârsuyu civarında altı eşkıyanın halka zulm ettikleri bunlardan ikisinin yakalandığını diğerlerinin de yakalanarak gasp ettikleri mallarının tahsil edilmesi ve suçlarının sübut olması sebebiyle emri şerif gelmedikçe serbest bırakılmamaları hususu 
devletin bu olaylara ne ciddiyetle eğildiğini göstermektedir: Bâzârsuyu kadısına gönderilen hükümde: Bâzârsuyu halkı gelip bu kazada oturan Osmân Çavuş oğlulları olarak tanınan Maruf Ali Çavuş ve kardeşi Osman, Hüseyin, Süleymân ve Nasluh oğlu Köse Hüseyin adlı eşkıyaların kendilerine iki yüz nefer süvari eşkıyayı katarak fakir halkın evlerini basıp mallarına, iaşelerine ve hayvanlarına saldırarak asayişi bozduklarını bildirmişleridir. Bunların mutlaka ele geçirilip halktan gaspettikleri mallar alındıktan sonra hak ettikleri cezanın verilmesi çin yeniçeri ocağında sabıka orta çavuş olan Abdi vasıtasıyla emir gönderilmişti. Adı geçen eşkiyalardan Osman ve oğlu Süleyman yakalandıklarını bildirip, bundan evvel adı geçen ve mübaşir tayin olunanın marifetiyle zorla ele geçirdiklerinin tahsili, adı geçenlerin soruşturmaları bitmeden salıverilmemeleri hususunda hüküm beyan etmişlerdir. Halkın hak ve hukukları tahsil olunduktan sonra da serbest bırakılmayıp gereği gibi tutukluluklarının devamı emir edilmiştir. Evâsıt-1 Zâ Sene 1111/ Mayıs 1700 (BOA.MD 111-1041).

Eşkiyalık olaylarını araştırmak üzere atanan Abdi Çavuş'un görev mahallinde rüşvet aldığı, halkın malını gasp ettiğini ve etrafına topladığı eşkıyalarla birlikte halka zulm ettiğini, asayişi bozduğunun tespit edilmesi üzerine bu durumu çözmek için görevlendirilen Mehmet Çavuş’tan bölgedeki kadılarla koordineli çalışarak bu belayı defetmesini ve malları gaspedilenlerin mallarının iade edildikten sonra İstanbul'a getirilerek cezalandırılması gösteriyor ki: devlet görevlilerinin de zaman zaman bulundukları yerlerde defetmeğe gittikleri bu şakilelerle işbirliği yaparak menfaat sağladıkları da bu asayiş olaylarında ehl-i örf'ünde katkıları olduğunu ortaya koymaktadır: Trabzon, Giresun, Bâzârsuyu, Ebulhayır, Akköy, Bayrâmlı, Ulubey, Pençşembe kadılarına ve Trabzon'da yeniçeri zabiti Deveci Salih'e ve zikrolunan kazalardaki yeniçeri serdarlarına gönderilen hükümde:

Bundan evvel eşkıya teftişi için emri şerifimle tayin olunan yeniçeri çavuşlarından Abdi Çavuş zikrolunan kazaların her bir kazadan yüzer ve ikişer yüz kuruş aldığından başka halkın bazılarıyla ihtilaf içinde oldukları, mallarını yağma ve talan ettiğini, bazılarının da at, katır ve kısraklarını gasp ettiği bildirilmiştir. Halkın hak ve hukuku doğrultusunda alacakları tahsil edildikten sonra durumun teferruatlı olarak aydınlatılması için tekrar ocak tarafından mübaşir tayin olunan Mehmed Çavuş Giresun'a vardığında adı geçen Abdi Çavuş emri şerife itaat etmeyip Giresun'da kendisine tâbi kırk elli nefer eşkıya ile kendisini şikâyet edenlere zülüm etmeğe devam etmiştir. Kadıların arz ve birkaç kasaba ahalisinin mübaşeretiyle adı geçenin İstanbul'a gönderilmesi istenmiştir. $\mathrm{Bu}$ işle görevlendirilen Mehmed zîde’nin marifetiyle Abdi Çavuşun hazır bulundurulması ve halkın sabit olan haklarının alındıktan sonra Divan-1 Hümayunumda 
icap eden cezasının verilmesi için son derece titiz davranılmasını, itaatsizlikte bulunan Abdi Çavuş zikrolunan kazalardan her hangisinde olur ise mutlaka yakalanıp zülmen el koyduğu malların geri verilerek firar ettirilmeden İstanbulda hazır bulundurulmasını ve dergâh-1 mu'allâm yeniçerilerim ağası olan İbrahim Ağa'ya verilen tasdikli belgeye göre davranılması için emir yazılmıştır. Evâhir-i Zâ Sene [1]112 / Mayıs 1701 (BOA.MD 1111430).

Devletin üst düzey yöneticilerinin de halkın inançlarını istismar ederek menfaatleri doğrultusunda sömürdüklerine dair Selimiyye Cami’nde meydana gelen bir olayla ilgili kayıtta: Eski hükümdar Sultan IV. Muhammed Han'ın zamanlarında sarayı atik teberdarlarından miri miran rütbesine ulaşmış ve birkaç sene de Trablus eyaletinde hükümet görevi yürütmekle görevlendirilip bazı yolsuzluklara karışıp hapis ve sürgün cezası alan Benli Hüseyin Paşa uzlete girmişti. Bu yoksulluk ve zor hayattan kurtulmak için etrafında topladığı bazı insanlarla Selimiyye Cami’nde sabah namazı sonrasında kendisi ile ittifak kuran eski Niş vekili Musa Ağa ile birlikte minberde fitne uyarmak üzere cemaate hitap ettiler. Ama kimse itibar etmeyip cemaat derhal dağıldı. Kendisine tabi olanlar da pişman oldular. Durum padişaha ihbar edilince orada işe karışanlar teker teker çağrıldı. Benli Hüseyin'in en yakın danışmanı olan Kürd Hüseyin Bozcaada’ya sürgün edildi. Daha sonra artlarından görevliler gönderilip ikisi de Ergene Kalesinde katl edildiler. Kelleleri Bab-1 Humayun'un önünde rezil bir şekilde arz edildi. Ayrıca ona destek veren Arap asıllı bir tanınmaz kişi ile birlikte çok sayıda suçlu da yakalanıp cezalandırıldı. Bir kısmı üç şerefeli camiide cezalandırıldı. Birkaç kişi Tunca Nehri’ne gönderildi, orada ölüm cezası ile cezalandırıldı Rabiulahir 11105 / Kasım-Aralık 1693 (Özcan, 1995: 503-504).

\section{Balkanlar'daki Olaylar}

Devlet görevlilerinin halkın da desteğini sağlayarak dağlarda saklanan eşkıyanın bertaraf edilmesi için ortak mücadele yaparak eşkıyanın bir daha bu bölgelerde barınmamasının sağlanmasına değinilmiştir. Dağlarda saklanan eşkıyanın yakalanması için Niğbolu Sancağı'nda olan kaldılara, kethüda erleri ve yeniçeri serdarları ve sair ayan1 vilayet iş erlerine hüküm gönderilmiştir: Adı geçen sancakta bazı sarp dağlarda haydut eşkıyalarının sığınarak oralarda konuşlandıkları ve asayişi tehdit ettikleri haberi alınmıştır. Bunun üzerine emri şerîfimle tayin olunan bostancı marifetiyle o dağların civarında olan kazalardaki ahalinin de desteğiyle dağlarda saklanan eşkıyanın yakalanması için gereği gibi dikkat eylemeniz hususunda emir yazılmıştır. Evâil-i Z Sene 1106 / Temmuz 1695 (BOA.MD 107-31). 
Balkanlarda hareket halindeki eşkıyanın geçtikleri bölgelere zarar verdiklerinden yapılan takip sonucu ve alınan istihbarat neticesinde bölgedeki görevlilerin mesuliyetinde meskun halkın da desteğiyle bu asayiş durumunun önlenmesi istenen emirde: Tunca Nehri'ni aşıp Vidin tarafına firar eden eşkıyaların yakalanması için merkezden emir gönderilmiştir. : Vidin tarafından Vidin Paşası ve bostancı ustalarının taarruz eyledikleri otuz nefer haydutun Girâr ve Fakihli adlı köylerin yakınındaki vakıf değirmeni yanından Tunca nehrini geçerek kazanıza firar etmişlerdir. Edirne bostancı başı Mustafa'nın makama durumu arz etmesi üzerine adı geçen bostancı başı'nın görevlendirilerek zikredilen haydutların yakalanmaları için başlarına yetkili kişilerin tayin edildiği işe yarar adamlarla üzerlerine gönderilerek bulundukları mahallerdeki adamlarının da yardımı alınarak oluşturulan silahlı birliklerle adı geçen eşkıyanın mutlaka getirilmesi için bunların yakalanarak Edirne'de Divanın huzuruna çıkarılmaları için emir yazılmıştır. Fî Evâhir-i S Sene [1]107 / Ekim 1695. (BOA.MD 107-78).

Tekfur dağına giden yol üzerindeki köprüye bir kısım eşkıyanın musallat olduğu ve bunların çevreye zarar vererek bölgedeki meskun insanlara zarar verdikleri haberinin alınması üzerine Edirne Bostancıbaşı bu durumu araştırmak üzere görevlendirilmiştir. Gönderilen hükümde anılan köprünün çevresindeki bölgede yaşayan insanlara zarar vermeden tafsilatlı bir araştırma sonucu halka zarar veren bu eşkıyanın tespiti ve bunların yakalanarak bir an önce orduya teslimi bildirilmiştir. Fî Evâhir-i L. Sene [1]108/ 17 Mayıs 1697 (BOA.MD 110-18)

Eşkiyanın büyük gruplar halinde soygun, yağma ve talan yaptıkları gibi bazı kasabaları işgal ederek zülumlerinin doruğa çıktığı da olmuştur. İvraca ile Rahova arasında bayrak ve flamalarıyla dolaşan yedi piyâde ve süvârî eşkıyâsı Rahova kasabasını işgal ettikleri yirmi insanı şehit ettikleri, birçok insanı yaraladıkları, bir kısmını esir ettiklerini, halkın mallarına elkoydukları haberi üzerine; Niğde Kadısı ve diğer görevliler sert dille uyarılarak görevlerini gereği gibi yapmadıklarından dolayı iş bu mecraya kadar gelmiştir. Bu kusurlarını kapatmak ve bu belayı def etmek için hepsinin işbirliğiyle hareket ederek bu taifenin ortadan kaldırılması hususunda zaman kaybettirilmeden tedbirlerin alınması, gerekli hassasiyetleri göstermeyen yöneticilerinde sert bir şekilde cezalandırılacağı bildirilmiştir. Fî Evâil-i Za. Sene 1108 / 27 Mayıs 1697 (BOA.MD 11043). Ayrıca Vidin muhafızı Hasan Paşa, eski Tımaşvar Beyi Hasan Paşa, Bostani ustalarından Ahmed Usta (h, 58, 74, 86, 116) emrindeki yeniçeri, cebeci, topçu, kale muhafızlarıyla birlikte Rahova'daki eşkıyanın ve yörede bulunan diğer eşkiyaların temizlenmesi için görevlendirilmişlerdir. 
Niğbolu Mütesellimine gönderilen hükümde de hâlâ o taraflarda bulunan eşkıyanın ortadan kaldırmak üzere bulunan tüm kuvvetlerin üzerine komutan tayin edilerek eşkıyanın bulunduğu bölgelerde temizlenmesiyle görevlendirilmiştir. Bundan sonra o civarda bir ferdin eşkıya tarafindan zarar görmesinde Mütesellim ve görevlilerin birlikte sorumlu oldukları, ihmali bulunanların isim durumlarını beyan eden raporlarla birlikte bildirilmesinin emir edilmesi konuya verilen önemi ortaya koymaktadır. Evâsit-1 Za. Sene 108 / 17 Haziran 1697 (BOA.MD 110-85)

Balkanlarda Filibe civarlarında Karaca adında eşkıyanın yaya ve süvari birliklerle soygun yaptıkları meskun halka zarar verdikleri haberi üzerine yeteri sayıda asker tayin edilerek bölgedeki kadı ve idarecilerin tamamı görevlendirilerek koordineli çalışmaları emir edilmiştir. İşbirliği halinde dar geçitlerin ve boğazların tutularak eşkıyaların yakalanarak hukuk üzere işlem yapılması için Edirne'ye getirilmeleri, yakalananlara işkence eziyet yapılmaması, mücadele esnasında yerli halktan her hangi bir angarya hizmet istenmemesi ve iyi davranılmasının istenmesi, asayişin sağlanmasında hukuka azami derecede riayet edildiğini ortaya koyan emirde: Karaca adlı eşkıyanın seksen süvari ve elli kadar piyade yol kesen eşkıyasıyla birkaç zamandan beri Hasköy, Filibe, Tatarbazârı, Srnakov ve Zihne civârında gezip halka, vilayet sakinlerine zulüm ettikleri, kamu malına zarar verdikleri bildirilmiştir. Bunların ele geçirilmesi için Ordu-yı Hümayundan yeteri kadar asker tayin olunarak mevcut mahalli kuvvetlerle birlikte görevlendirilmişlerdir İş erlerinden görevde olmayanlar Edirne bostancıları ustalarından mübaşir tayin olunan Usta zîde marifetiyle birlikte kazanızda ve diğer mahallerde haber alındığında cümleniz yardımlaşarak ittifak-halinde üzerlerine varıp kaçacakları derbent ve boğazları da tutarak her ne şekilde olur ise olsun mutlaka ele geçirip Edirne Divanına getirilmeleri ve yapmış oldukları kötülüklerin ortadan kaldırmaya ihtimam göstermeleri buyrulmuştur. Bunlardan özür beyanında bulunanlara işkence edilmesi kati şekilde yasaklanmıştır. Bunların şer ve ziyanlarını halk ve beldeler üzerinde def etmek için bütün görevlilerin gerekli hasasiyaeti göstermeleri, halktan bir ferde haksızlık yapılmamasını ve kendi hallerinde olanlara her hangi bir hak ihlalinden bulunulmaması hususunda hüküm yazılmıştır. Evâil-i Z Sene 1108 / Haziran 1697 (BOA.MD 109-10).

Eşkiyaların belli bölgeleri kontrolleri altına aldıklarını ortaya koyan kayıtta: Çirmen, Tatarpazarı, Filibe, Doniçe, Hasköy, Gümülcine, Kızanlık tarafından Uzuncaovaya varıncaya kadar yollar üzerinde ve bölgede bulunan eşkıyanın temizlenmesi için Edirne Bostancıbaşısı Hüseyin Usta görevlendirilerek bir fert kalmayıncaya kadar bölgedeki kuvvetlerle birlikte üzerlerine gidilmesi ve ayrıca bölgedeki teftişin aralıksız sürdürülmesi bu konudaki sürekliliğe azami riayet edilmesi 
bildirilmiştir. Ayrıca Samako, Doniçe, Köstendil, Cuma pazarı, Menlik, Razlık, Norakop kadıların, ayan-1 vilayet ve iş erlerininde Hüseyin Usta ile birlikte görevlendirilerek bu bölgelerdeki eşkıyanın lojistiğini keserek mahalli kuvvetleri de mücadeleye dahil ettirilerek bu olayların son bulması önemle bildirilmiştir. Evasıt Z. sene 108 / 22 Haziran 1697 (BOA.MD 110- 349, 351, 352)

Vidinden Niğbolu'ya kadar ve Morova ve Tuna nehirlerinin buluştukları yerde bulunan eşkiyanın halka zarar verdikleri mallarını gasp ederek zulüm ettikleri haberi alınmıştır. Bunların ortadan kaldırılması için Vidin muhafızı Hasan Paşa ve emrinde Eflak voyvodası beş yüz askeriyle birlikte görevlendirilerek yerli halkında desteğini sağlayıp eşkıyayı kanun üzere hak ettikleri cezaya çarpıtılmaları hususunda hiçbir gecikmeye ve ihmalda bulunmadan mücadele edilmesi, bölgenin tamamen temizlenmesi bildirilniştir. $\mathrm{Bu}$ mücadele esnasında yerli halkın zarar görmemesi konusundaki titiz davranılmasının vurgulanması ise halkın eşkıyadan uzak durması açısından titiz davranılmıştır Evail M. 1109 / 21 Temmuz 1697 (BOA.MD 110-380).

Kendilerini çeşitli görevlerle tanımlayarak halkı haraca bağlamaya çalışan kişilerinde olduğu zamanla olmuştur. Arnavut'un Usturmca kazasında yüz yirmi kişi sekban olarak görevli bulunmamasına rağmen kendilerini sekban olarak tanıtarak halktan zorla bize bin kuruş vereceksin diye köy köy dolaştıkları halka eziyet ettikleri tespit edilmiştir. Kazanın kadısına hüküm gönderilerek Arnavut'da sekbanlığın bulunmadığından dolayı giriştikleri bu görevin yasak olduğunu ve derhal terk etmeleri hususunda uyarılmaları ve halkın ittifakı sağlanarak bunların martolos olarak görevlendirilmeleri bildirilmiştir. Eğer kabul etmeyip aynı hal üzere devam ediyorlarsa ortadan kaldırılmaları emir edilmiştir Evail M. 1109 / 21 Temmuz 1697 (BOA.MD 110406).

Bazı bölgelerin uzun zamandan beri eşkıyaların barındıkları buraları eşkya yatağı haline getirdikleri, bu bölgede geçenlerin mallarıyla birlikte mağaralarda alıkoydukları, eşkıyalık olayının cereyan ettiği bölgede devlet görevlerinin bu belayı def etmek hususunda görevlerini yapmadıkları gibi onlara yardımcı oldukları bilgisi üzerine gerek devlet görevlileri gerekse halktan yardımcı olanların dikkatli bir araştırma sonucu soruşturularak suçu sübut olanların sicil kayıtlarıyla birlikte Edirne divanına istenmeleri olayların çok yönlü araştırılarak bunun kökten halledilmesi yoluna gidildiğine dair fermanda: Bundan evvel zuhur eden haydut eşkıyaları Karakādı oğulları ile eşlerini eşyalarıyla birlikte gasp ettikleri, bunları Filibe kazasına bağlı Dranova adındaki köyün civarında bulunana mağarada hapis etmişlerdir. Ad1 geçen bostancısı haber alıp 
üzerlerine varmak teşebbüsünde iken Veli Şatırın mutasarrıf olduğu zeameti olan köylerinden Filibe kazasına bağlı Pavliçko adındaki karyeden eşkiya Çodar'ın kaynatası Karaca, oğlu, oğulluğu Kalaycı ve adı geçen karyenin papası haber vermeleriyle mahpus ettikleri kişileri eşyalarıyle birlikte beş gün evvel firar ettiklerini yapılan gizli araştırma sonucunda tespit edilmiştir. Bunların on iki seneden beri Dranova, Pavliçko, Boğud, Çukur ve Direcik Yenicesi'nden saklandıklarını, buranın her yönüyle eşkıya yatağı olmaya müsait olduğu, otuz gün burada barındıkları ve iaşelerinin de sağlayan halkın bir kısmı ve subaşı'nın lojistik destek sağladığı haberi alınmıştır. Gelen emirde; eşkıyaya yardımcı olup kollayan gerek halktan gerek subaşı ve diğerleri her kim olursa olun vilâyetin itimat edilen güvenilir kimesnelerden gereği gibi soruşturulurak suçu sübut olanların sicil kayıtlarıyla birlikte Edirne Divanına gönderilmeleri, suçu olmayanların her hangi kötü muameleyle karşılanmamaları hususunda gerekli hassasiyeti gösterilmesi bildirilmiştir. Evâhir-i M Sene [1]109 / Temmuz 1697 (BOA.MD 109-81).

Firecik'de yağma, talan ve katilde bulunan eşkıyanın varlığı alınan istihbarat üzere tespit edilmiştir. Bu açık olan durumun araştırılması ve yöneticilerin ihmalinin olup olmadığının tespiti açısından tafsilatlı rapor istenmesi bu konudaki titizliği gösteren belgede: Firecik civarında bazı eşkıyanın peyda olup kasaba dâhilinde nice kimesnelerin hanelerin basıp nüfuslarını katlettiğini, mallarına el konulduğu haberi alınmıştır. Bu kadar aşikâr olan eşkıyalığın şimdiye değin varlığının bildirilmemesindeki ihmal ve tembellik gösterilmiştir. Şimdi belirtildiği şekilde o civarda eşkıyanın varlığı, faaliyetleri ile ilgili ayrıntılı bir şekilde rapor tanzim edilerek bildirmeniz emredilmiştir. Evâil-i S Sene [1]109 / Ağustos 1697 (BOA.MD 109-85).

Petriç kazasına bağlı bir çiftin yaptığı eşkıyalık ve soygun Müslümanların şahitliğiyle de tespit edilmiştir. Bunlar yapılan tembih ve telkinlerle de vazgeçmeyip aynı hallerini sürdürüyorlarsa yakalanarak Kavala kalesine haps edilmesi ve ferman gelmedikçe de serbest bırakılmamaları, devletin caydırıcılığı sadece inzibati tedbirlerle yapmadığını gösteren hükümde: Kavala paşasına, Petriç kadısına ve Kavâla Kal 'ası dizdarına hüküm ki: Bereketli kadısı Mevlana Mehmed mektup gönderip Petriç kazasına bağlı Leşeyh adlı karye sakinlerinden sabıka Çolak Ahmed adlı kişinin eşi Sitti hatun eşkıya kıyafeti giyerek eşkıyalık yaptığı, mal gasp ettiği, nüfus katlettiği Bereketli kadısı tarafından bildirilmiştir. Bu husus ayrıca mahallinde tarafsız Müslümanların şahadetiyle de tespit edilmiştir. Bu durum aynı hal üzere devam ediyorsa, konun araştırılıp ortaya çıkarılması için emri şerif doğrultusunda bilirkişi tayin edilerek yapılan araştırma sonucunda yapılan tembih ve telkinlerle de vazgeçmeyip aynı şekilde devam ettiği bilgisi teyit ettirildiğinde, halkın can ve mal güvenliği açısından Kavala kalesine hapsedilerek 
ferman gönderilmedikçe serbest bırakılmaması emir olunmuştur. Evâsıt-1 S Sene [1]109 / Eylül 1697 (BOA.MD 109-91).

Halka zulüm eden, iyi davranmayan ve halkı devletten soğutan Kandiya Muhafizı ve eyalet göreviyle görevlendirilen Fındık Mehemmed Paşa'nın yapılan araştırmalar sonucu suçları sübuta erdiğinden dolayı cezalandırıldığına dair kayıtta: Girit adasında Kandiya Muhafızı olan Vezir Fındık Muhammed Paşa'nın zulüm ve haksızlıklarından rahatsız olan ada yerlileri durumu şikayet edince Rikab kaymakamı Osman Paşa'ya Hanya, Hanya'da olan İsmail Paşa'ya Kandiya muhafizlığı menşuru gönderildi. Muhammed Paşa'nın keyfiyetinin yerinde araştırılıp devlete bildirilmesi için de Kapıcıbaşı Halepli Ahmed Ağa atandı. İsmail Paşa da Kandiyya gittiğinde Muhammed Paşa'nın kendilerine zulüm ettiğini ve haksız yollarla altın alıp yolsuzluk yaptığını söyledi. Durum araştırılıp sonucu vezarete bildirilince Sultan'ın emri ile cezalandırıldı. Ölüm fetvası çıkarıldı. Böylece ölüm cezası tatbik edildi Cemaziyelahir 1105 / OcakŞubat 1694 (Özcan, 1995: 516-517).

\section{Irak, Suriye ve Diğer Bölgelerdeki Olaylar:}

Dört karyede Ekrad eşkıyalarının zulüm ve baskısından dolayı yerlerini ve yurtlarını terk eden ahalinin tarafinızdan yerleştirildikleri Hama ve Humus halklarıyla uyum içinde değillerse kendi köylerine tekrar iskan edilmeleri istenmesi devletin ferdin yerleşme hürriyetine verdiği önemi gösteren hükümde: Rakka beglerbegisine, Halep, Hama, Humus, Antakya, Payâs, Adana, Mar 'aş, Âyıntab, Ruha, Birecik ve Malatya kadılarına gönderilen hükümde: Valide Sultan Kethüdası gelip müşarü'n-ileyhânın mutasarrıf olduğu hassa karyelerinden Türkmân, Çoma, Musabegli ve Şeyhü'l-hadîd adlı karyelerinin re 'ayasından bazıları arazilerinde Kürt eşkıyasının zulüm ve baskısından dolayı dağılan ve perişan olan halkın yeniden bulundukları mahalde iskân ettirilmeleri hususunda gönderilen emri şerifte; "Beyler Beyi ve senin Kapucu başı Hasım Mehemmed'in Hama ve Humus taraflarına iskân ettirdiğiniz kavimlerle aynı yaşam tarzı ve coğrafi şartlarda bir uyumsuzluk varsa vaya buradaki sakinlerle uyum içinde değilseler durumlarına uygun şekilde iskân edilsin”. Evâsıt-1 Zâ Sene [1]108 Haziran 1697 (BOA.MD 110-97). Bu kayıt Osmanlı Devletinin yerleşme ve seyahat özgürlüğüne gösterdiği özenle birlikte ferdin huzur ve mutluluğunu esas alarak her yeri yaşanır halde bulundurmasına azami titizlik göstermiştir.

Merkeze uzak olan vilayetlerde uzun süren savaşlar sebebiyle siyasi bir mahiyet kazanan ve hükümetin ilgisizliği yüzünden uzun süre devam eden isyanlardan olan, bir yanda Şehrizor taraflarında hüküm sürerken diğer taraftan komşu ülkelerle ilişkilerin 
bozulmasına da yol açan ve uzun süre devam ederek devleti uğraştıran isyanlardan biri de Bebe Süleyman İsyanı olmuştur. Bu isyanın bastırılması için devlet Diyarbakır Valisi ve bölgedeki diğer yöneticileri de Bağdat valisinin yardımına gönderildiğine dair fermanlarda: Diyârbekir vâlisi Vezîr Hüseyin Paşanın emrinde bundan evvel silahlandırılmış kapı halkından bir çok asker, Diyârbekir eyâletinin zü'amâ, erbabı tımar, alay beyleri, eyalette bulunan hükümet ve sancak mutasarrıfları, Diyarbakır'ın dört yüz yerli neferi ile birlikte Bağdat'a görevlendirilmiştir. Görev mahalline giderken Musul'a vardığında Bağdat valisi Vezir İsmail Paşa'nın da Bebe Süleyman üzerine bazı asker ile görevlendirildiği, adı geçen eşkıyanın üzerine vardığında hakkında sayısız şikâyetler olduğundan her nasıl olursa olsun yakalanıp getirilmesi için tekrar tekrar emri şerifler yazılmıştır. Ancak halen adı gen eşkıya ile ilgili şikâyetler devam etmekte olduğundan görevlendirilen vüzera, Mir-i Miran, ümera ve sair askeri birlikler eşkıyanın üzerine gönderilmesi, ortadan kaldırılması için o civarda Mirâhor-1 sânî Bayrâm da tayin edilerek gönderilmiştir. Emri Şerifte:

Şimdi sen ki vezir-i müşarünileyhsin emri şerifim vardığında bu konu hal edilmemiş ise kata tereddüt ve duraksama göstermeksizin seninle görevlendirilen bütün askerlerle ittifak ve ittihat ile bu kişinin üzerine varıp yakalayarak der-i devlet-medarıma bildiresin ve Şehrizor hududunda bulunmazsa izni şerifim olmadıkça geri Şehrizordan devam ederek her hususta basiret ve hassasiyet üzere hareket eyleyesin. Allah sizi korusun eğer bu eşkiya bu defa da ele geçirmez veya orada bulunmaz ise cümleniz orada kış ve yaz kalarak onu ortadan kaldırmak için lazım gelen her türlü tedbir alınsın. Buna rağmen bu kötü adam ele geçirmezse o hudut ve sınırın hukuk nizamı doğrultusunda olan ahvâlin her şekilde duyurularak hiç kimsenin gaflet ve tembellik sebebiyle bir emr nâmülâyim uygulanmasında son derece ihtimama göstererek bu kötü insanın ve durumun ortadan kaldırılmasında sınır nizamname hükümlerinin acil zaruri tedbirlerin alınması hususunda emir yazılmıştır. Fî Evâsıt-1 S Sene 1111 / 1699 (BOA.MD 111-309).

İsyanın II. Mustafa döneminde değişik zamanlarda ve değişik yerlerde ortaya çıkmış olup, uzun süre devam ettiği, komşu ülke olan İranla ilişkilerin bozulmasına bile sebep olduğundan çok yönlü bir şekilde tedbirler alınarak bu isyanın tamamen bastırılması ve asilerin ortadan kaldırılması hususunda yapılan uzun mücadele sonucu isyanın bertaraf edildiği kayıtlardan anlaşılmaktadır. II. Mustafa bu tür eşkıyalık olaylarının önlenmesi için bir yandan teftiş yapmak üzere valiler tayin etmiştir. Devlet merkezinden uzak eyaletlerdeki Bebe Süleyman gibi isyanlar siyasi mahiyet kazanmıştır. Şehrizor tarafında hüküm süren bu şahıs zorbalıklarda bulunarak İrana ait bazı yerleri işgal etti. 1699'da Bağdat valisi Hasan paşanın komutasında gönderilen kuvvetlere yenilince Hakkariye kaçtı. (Özcan, 2006: 275-280) 
Bebe Süleyman İsyanları: II. Mustafa döneminde Basra civarında eşkıyalık faaliyetlerinde bulunan "Mani" ve özellikle ortaya çıktığı süreçte ve sonrasında devleti bir hayli uğraştıracak olan "Bebe Süleyman" isyanları önemlidir. Bu isyanlara defter kayıtlarında ilk defa 1109 Zilkadesi'nin başlarında rastlanılmaktadır. Sultan Mustafa Basra Urban'ından Mani isyanının bastırılması için Acem hududundaki hanlar ve Şah'ın elçisi ile ortak hareket edilmesine dair Bağdad valisine (BOA.MD 110-1828), yine Acem ile işbirliği içinde Bebe Süleyman isyanının bastırılması için de İmadiye hakimine emirler göndermektedir.( BOA.MD 110-1829). Hatt-1 Humayun ile verilen bu iki hükmün ardından özellikle Bebe Süleyman isyanına dair mezkur tarihten başlayarak Van ve (hüküm:1831) Musul (hüküm:1834) valilerine, Eğil (h.1835), Çermik (h. 1836) Tercil (h. 1837) ve Genç (h.1838 )Hakkari ( 1858 ) hakimlerine ve başka sancak beylerine ve bazı aşiret reislerine ( 1856 ve 1862. hükümler ) hükümler yazılmıştır. Bunca alınan tedbirlere ve asker tevdilerine rağmen İsyan bastırılamamış H. 1111/1700 Şevvalinin sonuna (24 Ocak 1700) gelindiğinde ise ancak Bebe Süleyman'ın iki oğlu yakalanarak kalabent edilmiştir (BOA.MD 111-971 ).Ardı arkası kesilmeyen bu isyan hareketi İran Devleti ile Osmanlı Devleti arasındaki ilişkilere yön vermiş, Sadrazam Amca Hüseyin Paşa tarafından İran Şahı'nın imadü'd-devlesi'ne gönderilen bir mektupta ise İran ile Osmanlı arasındaki sulhün devamı isteniş eşkıyalık yapan Bebe Süleyman ve adamlarının bertaraf edilmesi için Bağdat ve Halep valilerine tebligat yapıldığı görülüyür .(Name-i Humayun Defteri:5 Hüküm No: 180, sayfa no:510-513; ADVNSNMH.d. 5,180; tarih 1112 S 10. İran ve Osmanlı işbirliğinin en azından II. Mustafa'nın saltanatında Bebe Süleyman isyanını bastırmakta yetersiz kaldığını II. Mustafa döneminde Kerkük'te devlete değil Bebe Süleyman'a bağlılığından otürü beratı elinden alınıp timarı bir başkasına tevcih edilen Hüseyin'in durumunu bildiren Kerkük Miralayı Ali Mir'in arzından anlıyoruz (AE.SMST.III 283-22751).

II. Mustafa döneminde, Urban kabilesinin Basrada dört yıl boyunca sebep asayişsizliği defetmek için alınan geniş tedbirlerle ilgili Nusretnamede ki (Silahtar Mehmed Ağa) kayıtta: dört seneden beri Basra etrafına musallat olan Urban kabilesinden Şeyh Mani geçen senenin Zilhiccesinde Basra'yı işgal edip Vali Bazergan Vezir Halil Paşa mahiyetindeki yedi yüzaskeri gemilere koyup nehrin karşı yakasına geçirerek acem tarafında Ebûşehir adındaki mahallede tuttuğunu, beş yüz kapukuluyu hile ile şehirde alıkoyup kılıçtan geçirdiğini Bağdad Beylerbeyi Vezir Ali Paşa tarafından makamı hümayuna bildirdi. Adı geçen eyalette kargaşayı önlemek için Vezir Ali Paşa'nın eyaletinde bulunan hükümet, sancak beyleri, aşiret ve kabile reislerine ser-asker olarak tayin edilmiştir. Ayrıca Rakka beylerbeyisi Kürd Ahmet Paşanın kethüdası ve Musul 
beylerbeyi Erkenetli Süleyman Paşa, Şehrizor Beylerbeyisi Hayra Ali Paşa ve dört yüz askeriyle birlikte Diyarbekir beylerbeyi Vezir Topal Hüseyin paşa birlikte tayin edilerek bu kargaşaya son verdirilmiştir. (Topal, 2001: 131-132).

Anadolu’dan Rakka'ya sürülen Kürt ve Türkmen aşiretlerinin burada çıkardıkları isyanın bastırılmasında etkin olan yöneticilerin taltifi ve asilerin te'dibi hakkındaki bir kayıtta: beş seneden beri bütün Anadolu’dan Rakka’ya sürülen Kürt ve Türkmen taifesi evvelden halkın malı ve mülkünde bedava yiyip içip davarlarını ekinlerinde otlatıyorlardı. Eşkiyalarıda yol kesip soygun yaptıkları, vilayet valisi ve müfettişlerin yapmış oldukları gizli araştırmalar sonucu tespit edilmiştir. Aşiretlerine tabi olanların çoğunluğu padişah'ın fermânına ita'at ve iskanda sabit kalarak ziraatlarını sürdürmekte oldukları, diğerlerinin ise kendilerine isyanı bahane ederek tembellikte bulunarak avare avare dolaşmaktadırlar. Anadolu müfettişi Yusuf Paşa kılıçlı Kürtleri yanına alarak bu "türedi eşkıyasını" bozguna uğrattı. Ganimet ortaya çıktığında "' kılıçlı bizim hizmetkârlarımızdan olup aşağılık varlıklardır, onlar kılıcıyla geçinirler, biz böyle ıssız yerde neden oturmaya iktiza ederiz" diyerek aşiret sâhibi Hacı Mustafa ve Hacı İvaz oğulları on beş bin Kürt ve Türkmen eşkıyası, beş bin kadar evlerinden ayrılanlarla birlikte Rakka Beylerbeyisi Kürd Ahmet Paşa üzerine yürüdüler. Ahmet Paşa Murat suyunun iki mahallinde olan geçitleri muhafaza ederken eşkiyâ yaya geçidinden geçip o mahallin muhâfizlarını bozguna uğrattı. Ahmet Paşa bu haberi aldığında ansızın üzerlerine taaruz ederek onları bozguna uğrettı. Asi kürt ve Türkmen aşiretleri Rakka'ya yerleştirildi. Ahmet Paşaya'ya Bozok ve Çorum sancakları tevcih edildi. İsyanın bastırılmasında büyük yararlılıklar gösteren Yusuf Paşa da Rakka'ya atandı (Topal, 2001: 267-268).

Daha önce Rakka'ya yerleştirilen bu asi aşiretlerin tekrar eşkıyalık faaliyetlerinde bulundukları ve bunların dağıtılarak yerleștirilmeleriyle ilgili kayıtta: Rakka iskânından Beydilli cematinden Topal Assâf adlı eşkiya dört yüz ev ile baraka da üç bin kadar eşkıya barındırdığı, bunların Murat nehrini geçip Mumbiç ve o civarlarda yerleştikleri, devlet yöneticilerini tahrik ettiklerini, yanlarına fitne ve fesat kalabalıkları topladıkları haberi alan Rakka Beylerbeyi Vezir Yusuf paşa Raha'ya seksen bayrak kapusu levendiyle üzerlerine varıp önce onları iskana davet etti. Ancak bunların davete icabet etmeyip asiliklerine devam edince, iki saat kadar süren muharebede yüz civarında eşkiyayı ortadan kaldırıldı. Hama ve etrafında bulunan köylerle, kasabaların halkı arasında saklananları Fırat nehrinin diğer tarafinda itâ'at altına alarak ikâmete tabii tutturdu. Dağılmış durumda olanları da imkan dahilinde iskan edilmeye çalışıldı. İskan edilemayanler taife taife dağıldılar. Daha önceden Mümbiç’da iskan ettirilen Kilis Ekrâdı yine Kilise, Avşar, 
Cerid ve lekvan cematlerinin bir kısmı ile Maraş civarlarına firâr edenlerin de tekrar Rakka’ya iskan ettirildiler. (Topal, 2001: 350-351).

Devlet yöneticilerinin arasına sokulan fitne sonucu meydana gelen büyük olayların yarattığı asayişsizlikler ve iktidar mücadelelerinin cereyan ettiği bölgelerdeki huzursuzlukların devleti meşgul ettiğine dair kayıtta: Önceden beri ocaklık olan Tunus eyaletine mutasarrıf Vatan beyi Ramazan Bey'e bazı fesatlar gelip, ‘daha önce öldürülen büyük abin Ali Bey’in Oğlu Murad Bey seni ortadan kaldırıp yerine geçmek niyetindedir." Bunun üzerine Ramazan bey yeğenin gözlerine mil çekilerek deryâda vâki' Susa adlı kalesine hapis edilmesini emir etti. Lâkin mil çeken şahıs merhametli olduğundan, kaşlarını yakıp yüzünü bir ilaç ile şişirip muhtelif yerlerinden sarı sular akıttı ve gözleri kör oldu gibi etti. Bir gece kendisini korumakla vazifeli görevlinin gafletinden istifa ederek onu öldürüp, kaleden kaçtı. Urban dağına saklanan Murat beyin üzerine Ramazan bey asker gönderdi. Yapılan muharebede Ramazan bey'in askeri Murat beyle anlaşınca Ramazan bey bir yolunu bulup Tunus'a dogru firar ederek sümbeki askerlerine katıldı. Bindiği geminin dümeni ve kaptanı olmadığından Murat bey yetişip onu yaraladı ve karşı koyanları kılıçtan geçirerek Tunusu kendi himayesine aldı. Babasının öcünü almak üzere Cezayir üzerine yürüdü. Merkezden gönderilen kuvvetlerle yapılan uzun müzakere ve mücadele sonucu Murat bey de katledilerek ortadan kaldırıldı (Topal, 2001: 519-520).

\section{Sonuç}

Sultan II. Mustafa'nın saltanatı 1683'teki II. Viyana bozgunundan sonra olduğu için Osmanlı ülkesinin birçok farklı noktasında baş gösteren eşkıyalık faaliyetleri açısından oldukça sıkıntılı ve çalkantılı bir dönem olmuştur. Bu dönemde küçük grupların neden olduğu eşkıyalık girişimlerinin yanı sıra daha örgütlü, geniş katılımlı ve daha geniş bölgeleri etki altına alan şekavet hareketleri de yaşanmıştır. Bu olayların bir kısmı da yerel idarecilerin bulundukları bölgelerdeki de mevcut kargaşa ortamından istifade ederek onların teşviği ve kimi kanunsuz uygulamaları sonucu ortaya çıkmıştır.

Devlet, bu olayların önlenmesi için aynı anda farklı bölgelerdeki idarecileri görevlendirerek koordinasyon içinde mücadele etme yöntemini benimsemiştir. Özellikle bazı aşiretlerin çıkardıkları olayları bir başka aşireti kullanarak bastırmış veya şekavete sebep olan şeflerini resmi görevlere atayarak sistem içerisinde kalmasını sağlayıp girişilen hareketi etkisizleştirmeye çalışmıştır. $\mathrm{Bu}$ vesile ile bu gibi grupları Avrupa devletlerinde görüldüğü üzere imha ederek değil, bunları devlet mekanizması içinde kendisiyle bütünleştirerek gücünü artırmıştır. Diğer taraftan resmi kayıtlarda da 
görüldügü üzere eşkıyalara karşı verilen mücadelede halkın şikâyetleri dinlendikten sonra hakkaniyet üzere bir yargılama yapılarak bir karara varılması olayların önlenmesinde etkili olmuştur.

\section{Kaynakça}

AFYONCU, E. (2006). Sorularla Osmanlı İmparatorluğu, C.I, İstanbul: Yeditepe Yayınları,

AFYONCU, E. (2003). Sorularla Osmanl Imparatorluğu, C.III, İstanbul: Yeditepe Yayınları,

AKDAĞ, M. (1995). Türk Halkının Dirlik ve Düzenlik Kavgası Celali İsyanları, İstanbul: Cem Yayınevi.

AKDAĞ, M. (2014). Türkiye’nin İktisadi ve Iç̧timai Tarihi, Yapı Kredi Yayınları, İstanbul.

BOA. ADVNSNMH.d. 106, h.31, Fî Evâil-i Z Sene [1]106 / Temmuz 1695

BOA. ADVNSNMH.d. 107, h.78, Fî Evâhir-i S Sene [1]107 / Ekim 1695

BOA. ADVNSNMH.d. 108, h.829, Fî Evâil-i Sene [1]107 / Temmuz 1695

BOA. ADVNSNMH.d. 109, h.31, Fî Evâil-i Z Sene [1]106 / Temmuz 1695

BOA. ADVNSNMH.d. 108, h.1107, Fî Evâil-i Zâ Sene [1]107 / 7 Haziran 1696

BOA. ADVNSNMH.d. 109, h.10, Fî Evâil-i Z Sene [1]108 / Haziran 1697

BOA. ADVNSNMH.d. 109, h.13, Fî Evâsıt-1 Z Sene [1]108 / Temmuz 1697

BOA. ADVNSNMH.d. 109, h.81, Evâhir-i M Sene [1]109 / Temmuz 1697

BOA. ADVNSNMH.d. 109, h.85, Evâil-i S Sene [1]109 / Ağustos 1697

BOA. ADVNSNMH.d. 109, h.91, Evâsıt-1 S Sene [1]109 / Eylül 1697

BOA. ADVNSNMH.d. 110, h.18, Evâhir-i L. Sene [1]108/ 17 Mayıs 1697

BOA. ADVNSNMH.d. 110, h.28, Fî Evâsıt-1 Zâ Sene [1]108/ 26 Mayıs 1697

BOA. ADVNSNMH.d. 110, h. 43, Fî Evâil-i Za. Sene 1108 / 27Mayıs 1697

BOA. ADVNSNMH.d. 110, h.85, Evâsıt-1 Za. Sene 108 / 17 Haziran 1697

BOA. ADVNSNMH.d. 110, h.345, Fî Evâhir Sene [1]108 / 7 Temmuz 1697

BOA. ADVNSNMH.d. 110, h.349, Evâsit-1 Z. sene 108 / 22 Haziran 1697 
BOA. ADVNSNMH.d. 110, h.351, Evâsit-1 Z. sene 108 / 22 Haziran 1697

BOA. ADVNSNMH.d. 110, h.352, Evaâtt-1 Z. sene 108 / 22 Haziran 1697

BOA. ADVNSNMH.d. 110, h.380, Evâil-i M. 1109 / 21 Temmuz 1697

BOA. ADVNSNMH.d. 110, h.97, Evâil-i M. 1109 / 21 Temmuz 1697

BOA. ADVNSNMH.d. 110, h.97, Fî Evâsit-1 Zâ Sene [1]108 Haziran 1697

BOA. ADVNSNMH.d. 111, h.309, Fî Evâsit-1 S Sene 1111 / Ağustos 1699

BOA. ADVNSNMH.d. 111, h.1041, Fî Evâsit-1 Zâ Sene 1111/ Mayıs 1700

BOA. ADVNSNMH.d. 111, h.1430, Fî Evâhir-i Zâ Sene [1]112 / Mayıs 1701

BARDAKOĞLU, Ali (1995) “ Eşkıya”, Türkiye Diyanet Vakfi İslam Ansiklopedisi (DIA), C. 11, ss. 463-466, İstanbul.

Defterdar Sarı Mehmed Paşa (1995), Zübde-i Vekayîat, (Haz. Özcan, A.) Ankara: Türk Tarih Kurumu Yayınları.

DEMIR, U. (2006). Tarih-i Mehmed Giray, (Yayımlanmamış Yüksek Lisans Tezi: Marmara Üniversitesi Türkiyat Araştırmaları Enstitüsü.

DEMİRCİ S, Arslan H. (2012), “ Eşkıyalar ve Osmanlı Devleti: Maraş Eyaleti Örneğinde Devlet Görevlilerinin Eşkıyalık Faaliyetleri Ve Bunların Merkez-Taşra Yazışmalarındaki Yansımaları (1590-1750), Süleyman Demirel Üniversitesi, Sosyal Bilimler Enstitüsü Dergisi, Sayı: 16, ss. 47-76.

İLGÜREL, M. (1993). “Celali İsyanları”, (DİA), C. 7, ss. 252-257, İstanbul.

İLGÜREL, M. (1995). “Osmanlılarda Eşkıyalık Hareketleri”, DİA, C.11, ss. 466469, İstanbul,

İNALCIK, H (1988). “Adaletname”, DİA, C.1, ss. 346-347, İstanbul.

KAREN B. (2016). Eşkıyalar ve Devlet: Osmanlı Tarzı Devlet Merkezileşmesi, (Çev: Zeynep Altok), İstanbul: Tarih Vakfı Yurt Yayınları.

ORHUNLU, C.(2001). “Mustafa II”, Milli Ĕ̆itim Bakanlı̆̆ İslam Ansiklopedisi (iA), C.VIII, ss. 695-700.

ÖZCAN, A. (2006). “ Mustafa II”, DİA, C. 31, s. 275-280, İstanbul.

ÖZTUNA, Y (1983). Büyük Türkiye Tarihi, C.6, İstanbul: Ötüken Yayınevi. 
SHAW, S. (1994). Osmanlı İmparatorluğu ve Modern Türkiye, C.I, İstanbul: E Yayınları.

TOPAL, M. (2001). Silâhdar Findıklı Mehmet Ăga, Nusratname Tahlil ve Metin (1106-1133/1695-1725). (Yayımlanmamış Doktora Tezi), Marmara Üniversitesi Sosyal Bilimler Enstitüsü Türkiyat Araştırmaları Enstitüsü.

UZUNÇARŞILI, İ. Hakkı (1973). Osmanlı Tarihi, C.III, Ankara: Türk Tarih Kurumu Yayınları.

ÜNAL, M.A (2017). "Devlet İçi İktidar Mücadelesinin Bir Unsuru Olarak Eşkıyalık ve Ayrılıkçı Hareketler”, Osmanlıdan Günümüze Eşkiyalık ve Terör, (Ed. Osman Köse), Samsun 2017, s.3-10 